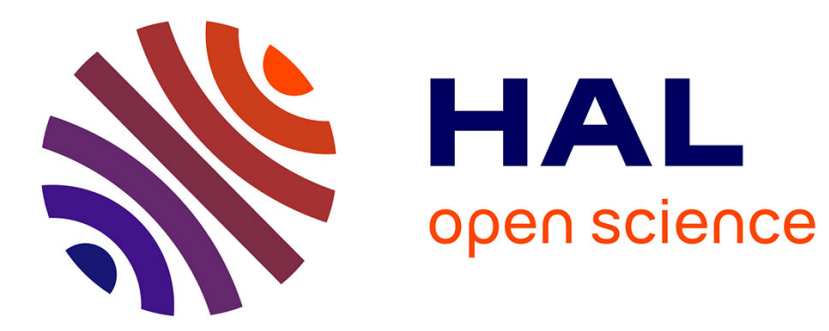

\title{
Comparing Techniques for Selecting Automation Technology
}

Erlend Alfnes, Maria Kollberg Thomassen, Marthe Bostad

\section{To cite this version:}

Erlend Alfnes, Maria Kollberg Thomassen, Marthe Bostad. Comparing Techniques for Selecting Automation Technology. IFIP International Conference on Advances in Production Management Systems (APMS), Sep 2016, Iguassu Falls, Brazil. pp.371-378, 10.1007/978-3-319-51133-7_44 . hal01615757

\section{HAL Id: hal-01615757 \\ https://hal.inria.fr/hal-01615757}

Submitted on 12 Oct 2017

HAL is a multi-disciplinary open access archive for the deposit and dissemination of scientific research documents, whether they are published or not. The documents may come from teaching and research institutions in France or abroad, or from public or private research centers.
L'archive ouverte pluridisciplinaire HAL, est destinée au dépôt et à la diffusion de documents scientifiques de niveau recherche, publiés ou non, émanant des établissements d'enseignement et de recherche français ou étrangers, des laboratoires publics ou privés. 


\title{
Comparing Techniques for Selecting Automation Technology
}

\author{
Erlend Alfnes ${ }^{1, *}$, Maria Kollberg Thomassen ${ }^{2}$, and Marthe Bostad ${ }^{1}$ \\ ${ }^{1}$ Norwegian University of Science and Technology, Department of Production and Quality En- \\ gineering, Trondheim, Norway \\ erlend.alfnesentnu.no \\ ${ }^{2}$ SINTEF Technology and Society, Industrial Management, Oslo, Norway \\ maria.thomassen@sintef.no
}

\begin{abstract}
Automation of industrial processes is a necessary step towards the Industry 4.0 vision. There are several justification techniques available that can help to improve chances for success in automation projects. A literature review on justification techniques and their usefulness is carried out. Based on the review, a set of criteria for evaluating justification techniques are developed. A case study is carried out in a company with an ongoing manufacturing system development project that includes decisions regarding processes and technologies that require a systematic evaluation and justification. Two justification techniques were selected and tested in the development project. The tests show that both justification techniques provide good support for the technology acquisition process. Strengths and weaknesses of the tested techniques are highlighted. The study suggests that the choice of method should depend on the type of acquisition process of a company, especially with respect to technology strategy, competences, and supplier relations.
\end{abstract}

Keywords: Operations strategy $\cdot$ Automation $\cdot$ technology acquisition $\cdot$ Justification techniques

\section{Introduction}

Manufacturing companies are forced to look for progressive automation technologies to keep their market share and maintain competitive $[1,2]$. The capability of the companies competitiveness is essential for their survival $[1,3]$. Automation technology has been the development key driver of processes in manufacturing plants since it entered the manufacturing industry $[4,5]$. Implementing an automatic system can result in cost savings within production or increased efficiency, productivity and competitiveness $[6$, 7]. However, the introduction of automation technology will need time to achieve successive implementation $[8,9]$. It is also important to be aware that automation can bring problems and failures and not necessarily immediate success [10]. Additionally, Frohm [8] states that increasing level of automation in unforeseen production situations can be

adfa, p. 1, 2011.

(c) Springer-Verlag Berlin Heidelberg 2011 
related to production disturbances, while Duncheon [11] list challenging cases like innovative products or products with short life cycle because of the uncertainty related to such production.

The development of manufacturing systems entail large investments, which will require justification of the decisions that are to be made $[2,4,12]$. The literature consists of many justification techniques for the acquisition of automation technology, but the use of such techniques in industry is limited. The existing techniques are criticised for being too time consuming, or not user friendly, or for putting too much weight on the financial aspects, or for a lack of sufficient support to the decision maker in certain phases of the selection process $[3,13-15]$. There is a need to verify the usefulness of such methods in the industry $[16,17]$.

The purpose of this paper is identify two justification techniques that support the main phases of an automation technology selection process, to test these techniques in a case, and evaluate their usefulness in practice. The main contribution is a set of criteria for evaluating justification techniques, and insights about the usefulness of two justification techniques in industry.

The paper is organised as follows. First, the methodological approach is discussed. Next, the most common justification techniques is reviewed. Two techniques are applied and evaluated in a case study. Finally, conclusions are presented together with suggestions for further work.

\section{Methodological Considerations}

This study is based upon a literature review and a case study of an automation selection and acquisition process. The purpose of the literature was to investigate the main criteria for evaluating and prioritising justification techniques. Based on the review, a set of criteria for evaluating justification techniques is developed. An single case study approach was chosen to ensure enough detail and in-depth insights about actual use of justification techniques in industry. The case company was selected because they have an ongoing manufacturing system development project that include decisions regarding several processes and technologies that require a systematic evaluation and justification. Case company data was collected in several iterations over a year. Most of the data were collected in workshops with case company representatives. Interviews and discussions with key personnel were carried out combined with plant visits.

\section{Theoretical Discussion}

Chan et al. [1] classifies justification techniques into the three groups; strategic, economic or analytic approach which can be used unaided or combined. The combination of strategic and economic approaches is a common combination since the strategic approach has direct tie to the goals of the firm, and the possibility of overlooking the economical and tactical impacts gets covered by the economic approach [1]. The economic approach is based on an evaluation of the economic aspects and can contribute to the final decision of choosing an automation technology [1]. The strategic approach 
involve analysis of competitive advantage, business objectives, research and development, and technical importance $[1,16]$.

\subsection{Justification Techniques}

The main phases that should be supported by a justification technique is technology strategy, analysis of operations competences and requirements, analysis of potential technologies, investments analysis, and implementation policy analysis [18]. The main justification techniques and their support for different phases are listed in Table 1.

Table 1. Justification techniques and the main phases they support.

\begin{tabular}{l|c|c|c|c|c}
\hline \multicolumn{1}{c|}{ References } & Strategic & Operations & Technology & $\begin{array}{l}\text { Invest- } \\
\text { ment }\end{array}$ & $\begin{array}{l}\text { Imple- } \\
\text { mentation }\end{array}$ \\
\hline Baines [13] & $\mathrm{X}$ & $\mathrm{X}$ & $\mathrm{X}$ & & $\mathrm{X}$ \\
Chan et al. [1] & $\mathrm{X}$ & $\mathrm{X}$ & $\mathrm{X}$ & $\mathrm{X}$ & $\mathrm{X}$ \\
Chuang et al. [19] & $\mathrm{X}$ & $\mathrm{X}$ & $\mathrm{X}$ & & \\
Durrani et al. [14] & $\mathrm{X}$ & $\mathrm{X}$ & $\mathrm{X}$ & & \\
Efstathiades et al. [20] & $\mathrm{X}$ & $\mathrm{X}$ & $\mathrm{X}$ & $\mathrm{X}$ & $\mathrm{X}$ \\
Farooq and O'Brien [21] & $\mathrm{X}$ & & $\mathrm{X}$ & & \\
Iakymenko [22] & $\mathrm{X}$ & & $\mathrm{X}$ & $\mathrm{X}$ & \\
Raafat [23] & & & & $\mathrm{X}$ & \\
Sambasivarao and & & $\mathrm{X}$ & & $\mathrm{X}$ & \\
Deshmukh [2] & & $\mathrm{X}$ & $\mathrm{X}$ & & \\
Shehabuddeen et al. [17] & & $\mathrm{X}$ & $\mathrm{X}$ & $\mathrm{X}$ & $\mathrm{X}$ \\
Thomassen et al. [18] & $\mathrm{X}$ & $\mathrm{X}$ & $\mathrm{X}$ & & $\mathrm{X}$ \\
Torkkeli and Tuominen & & & & \\
[24] & &
\end{tabular}

\subsection{Criteria for Selecting Justification Techniques}

An utilisation of justification techniques can contribute to evaluate important areas when acquiring automation technology $[1,15,25,26]$. The important areas can vary in the different techniques, which depends on their aim of support. However, it is essential that a technique contributes with enough support in the acquisition process [24], as well as evaluating the necessary area for the particular process $[3,13,14,24]$.

For a justification technique to be supportive in an acquisition of automation technology, it has to be applicable and well explained $[13,14,18]$. Such technique will be easy to follow and prevent unnecessary use of time or expertise. Effective techniques will reduce the time and work load for a practitioner. Additionally, production processes with special challenges will benefit justification techniques with the possibility of modifying evaluation areas $[17,24]$. The most important criteria for evaluating the usefulness of justification techniques is listed in Table 2. 
Table 2. Key criteria for evaluating the usefulness of justification techniques.

\begin{tabular}{lll}
\hline Category & Important elements & References \\
\hline Ease of & Effective in execution & {$[2,17,18,21,24]$} \\
performance & Applicable & {$[13,14,18,21]$} \\
& Well explained & {$[13,14,18,21]$} \\
\hline Covers & Include the important areas & {$[1,15,25,26]$} \\
necessary & Ability to evaluate distinctive areas for the process & {$[3,13,14,17,24]$} \\
areas & Guides the selection part of the acquisition process & {$[2,17]$} \\
& Guides multiple parts of the acquisition process & {$[13,14,18,21]$} \\
& Exclude the practitioner's "gut" feeling & {$[1,15,17,25,26]$} \\
\hline Type of & Combine strategic and economic approach & {$[1,16]$} \\
approach & Prioritise technology alternatives & {$[2,13,14,17,18,22$,} \\
& Evaluate with a visualising model & $24]$ \\
& Evaluate with a scoring model & {$[14,15,18]$} \\
& & {$[15,17,22,25]$} \\
\hline
\end{tabular}

\section{$4 \quad$ Case Study}

The case company is within the aerospace and defense industry. The company wants to automate a production line for medium and large caliber ammunition, where many operations currently are performed manually and several processes are very challenging to automate. Two justification methods were selected for testing. The APROS (Automation Project Selection) method [18] was chosen because it support all phases of a technology acquisition process. The technology selection framework [17] has a more limited scope, but were selected because it provides a set of scoring models that enables a thorough evaluation of a certain technology.

\subsection{The Automation Project}

The planned production line to be transformed into fully automated production line consists of stamping tracer and explosives (semi-automated), assembly (semi-automated), marking (fully automated) and packing (manual process). A mapping of the processes has shown that the assembly process seems to be the most challenging to automate, and a plan with milestones has been to automate the assembly process, Table 3 . 
Table 3. Milestones in the automation project.

\begin{tabular}{ll}
\hline Date & Activity \\
\hline 12.2015 & Project start in the production department \\
01.2016 & Tender sent for the assembly process \\
02.2016 & Meetings held with potential suppliers for the assembly process \\
03.2016 & Offers received from suppliers on the assembly process \\
04.2016 & Supplier selected for an automation technology in the assembly process \\
06.2016 & Order is placed for the selected automation technology on the assembly process \\
05.2017 & Automation technology for the assembly process is implemented \\
07.2019 & The production line is fully automated in the manufacturing company \\
\hline
\end{tabular}

\subsection{The Evaluation of Technologies}

The automation technology offers received from three different suppliers were evaluated with the two justification techniques in the case study. The first offer, technology alternative 1 , consists of robots processing and transferring one product at time between the stations. The second offer, technology alternative 2, consists of transporting pallets with multiple products. In addition, the input is handled by a robot and navigated with a camera solution. The last offer evaluated, technology alternative 3, consists of an input with a blister and transports multiple products with pallets. The practitioner picked out three parts of the assembly process for evaluation, which were the three most important parts in the assembly process to be supported by techniques. Three processes in assembly were selected for evaluation, 1) materialhandling between work station, 2) feeding components to a station, and 3) gluing and control.

Table 4. Results of the technology evaluation.

\begin{tabular}{lll}
\hline Part of the process & $\begin{array}{l}\text { Selected alternative in the first } \\
\text { technique }\end{array}$ & $\begin{array}{l}\text { Selected alternative in } \\
\text { the second technique }\end{array}$ \\
\hline Intern transport & Technology alternative 1 & Technology alternative 3 \\
Input & Technology alternative 2 & Technology alternative 3 \\
Glue applying and control & Technology alternative 1 & Technology alternative 3 \\
\hline
\end{tabular}

The more strategic evaluation performed by the APROS method suggested that the company should select technology 1 . The second justification technique gave scores with very small deviations (technology 1: 6,1, technology 2: 5,7, and technology 3: $6,4)$. The final decision was therefore to go for technology 1 , with robots processing and transferring one product at time between the stations.

\section{Discussion}

The two justification techniques point out different solutions, but the differences between the results of technologies are not so different with a closer look. The results are 
in close race in both of the techniques for each process, which make all results from the justification techniques valuable. The evaluation of the usefulness of the justification techniques is summarized in Table 5.

Table 5. Evaluation of the techniques based on evaluation criteria.

\begin{tabular}{|c|c|c|c|}
\hline Category & Criteria & APROS & $\begin{array}{l}\text { The tech. } \\
\text { selection } \\
\text { framework }\end{array}$ \\
\hline \multirow{3}{*}{$\begin{array}{l}\text { Ease of perfor- } \\
\text { mance }\end{array}$} & Effective in execution & $\mathrm{X}$ & $\mathrm{X}$ \\
\hline & Applicable & $\mathrm{X}$ & $\mathrm{X}$ \\
\hline & Well explained & $\mathrm{X}$ & \\
\hline \multirow{5}{*}{$\begin{array}{l}\text { Covers necessary } \\
\text { areas }\end{array}$} & Include the important areas & $\mathrm{X}$ & $\mathrm{X}$ \\
\hline & Possibility to include additional areas & & $\mathrm{X}$ \\
\hline & Guides one part of the acquisition process & & $\mathrm{X}$ \\
\hline & Guides multiple parts of the acquisition process & $\mathrm{X}$ & \\
\hline & Exclude the practitioner's "gut" feeling & & $\mathrm{X}$ \\
\hline \multirow[t]{3}{*}{ Type of approach } & Combination of strategic and economic approach & $\mathrm{X}$ & $\mathrm{X}$ \\
\hline & Evaluate with a visualising model & $\mathrm{X}$ & \\
\hline & Evaluate with a scoring model & & $\mathrm{X}$ \\
\hline
\end{tabular}

Both justification techniques provides good support for a automation technology acquisition process. The APROS approach is suited to guide the complete acquisition process from establishing strategy to investment in technology. The APROS methodology supports multiple parts of the acquisition process, and this makes it possible to use the technique in different areas dependent on the practitioner's requirements. It is visual, highly effective, easy to understand, and evaluate important areas of the technologies. However, it should include earlier experience with the suppliers and their reputation, and does not explain the cost calculations well enough. The technology selection framework, only supports the core selection process in the acquisition of an automation technology. It is based on a detailed scoring model and is a more thorough justification technique. However, it is difficult to understand at first. It does not explain the meaning of the scores in the model, which made the practitioners insecure of how to understand the score scale. The cost calculations are not explained well enough. The choice of method therefor depends on the type of acquisition process a company is performing, and how well the technology strategy, competences, and supplier relations are established in the company.

\section{Conclusion}

This paper reviews justification techniques and test how such methods perform in practice. The main contribution is a set of criteria for evaluating justification techniques, and some insights about the usefulness of two justification techniques in industry. The application of two techniques in a case study showed that both techniques has strengths and weaknesses, and their applicability depend on the purpose and manufacturing environment for a technology acquisition process. 
Further work should be done to test justification techniques and evaluate their usefulness in case companies that has different technology challenges and manufacturing environments.

Acknowledgements. This research is supported by the Research Council of Norway through the research projects EFFEKT and Manufacturing Network 4.0.

\section{References}

1. Chan, F.T.S., et al.: Investment Appraisal Techniques for Advanced Manufacturing Technology (AMT): A Literature Review. Integrated Manufacturing Systems, 12(1): 35-47 (2001)

2. Sambasivarao, K.V., Deshmukh, S.G.: A Decision Support System for Selection And Justification of Advanced Manufacturing Technologies. Production Planning \& Control 8(3), 270-284 (1997)

3. Säfsten, K., M. Winroth, Stahre, J.: The Content and Process of Automation Strategies. International Journal of Production Economics, 110(1), 25-38 (2007)

4. Ordoobadi, S.M., Mulvaney, N.J. Development of a Justification Tool for Advanced Manufacturing Technologies: System-Wide Benefits Value Analysis. Journal of Engineering and Technology Management, 18(2), 157-184 (2001)

5. Jovane, F., Y. Koren, Boer, C.R.: Present and Future of Flexible Automation: Towards New Paradigms. CIRP Annals-Manufacturing Technology, 52(2): 543-560 (2003)

6. Frohm, J., et al.: The Industry's View on Automation in Manufacturing. In Proceedings of the 9th symposium IFAC on Automated Systems Based on Human Skills and Knowledge, France (2006)

7. Groover, M.P.: Automation, Production Systems, and Computer-Integrated Manufacturing. Prentice Hall Press (2007)

8. Frohm, J.: Levels of Automation in Production Systems. Chalmers University of Technology Gothenburg (2008)

9. Meredith, J.R.: Managing Factory Automation Projects. Journal of Manufacturing Systems, 6(2), 75-91 (1987)

10. Lindström, V. and Winroth, M.: Aligning Manufacturing Strategy And Levels Of Automation: A Case Study. Journal Of Engineering And Technology Management, 27(3), 148-159 (2010).

11. Duncheon, C., Product Miniaturization Requires Automation-But With a Strategy. Assembly Automation, 22(1), 16-2 (2002)

12. Parsaei, H.R., Wilhelm, M.R.: A Justification Methodology For Automated Manufacturing Technologies. Computers \& industrial engineering, 16(3), 363-373 (1989)

13. Baines, T.: An Integrated Process for Forming Manufacturing Technology Acquisition Decisions. International Journal of Operations \& Production Management, 24(5) 47-467 (2004)

14. Durrani, T.S., et al.: Managing the Technology Acquisition Process. Technovation, 18(8), 523-587 (1998). 
15. Granlund, A., Jackson M.: Managing Automation Development Projects: A Comparison of Industrial Needs and Existing Theoretical Support,: In Advances in Sustainable and Competitive Manufacturing Systems, Springer, 761-774 (2013)

16. Small, M.H., Chen, I.J.: Economic and Strategic Justification of AMT inferences from Industrial Practices. International Journal of Production Economics, 49(1), 65-75 (1997)

17. Shehabuddeen, N., D. Probert, Phaal, R.: From Theory to Practice: Challenges in Operationalising a Technology Selection Framework. Technovation, 26(3), 324-335 (2006)

18. Thomassen, M.K., B. Sjøbakk, Alfnes, E.: A Strategic Approach for Automation Technology Initiatives Selection. In Advances in Production Management Systems. Innovative and Knowledge-Based Production Management in a Global-Local World Springer, 288-295 (2014)

19. Chuang, M., Y.S. Yang, Lin, C.T.: Production Technology Selection: Deploying Market Requirements, Competitive and Operational Strategies, and Manufacturing Attributes. International Journal of Computer Integrated Manufacturing, 22(4), 345-355 (2009)

20. Efstathiades, A., S. Tassou, Antoniou, A.: Strategic Planning, Transfer and Implementation of Advanced Manufacturing Technologies (AMT). Development of an integrated process plan. Technovation, 22(4), 201-212 (2002)

21. Farooq, S., O’Brien, C. A.: Technology Selection Framework for Integrating Manufacturing Within A Supply Chain. International Journal of Production Research, 50(11), 2987-3010 (2002)

22. Iakymenko, N.: An Approach for Evaluating the Appropriateness of Automation in Manufacturing Processes with Increasing Product Mix. Norwegian University of Science and Technology, Faculty of Engineering Science and Technology, Department of Production and Quality Engineering, 57 (2014)

23. Raafat, F.: A Comprehensive Bibliography on Justification of Advanced Manufacturing Systems. International Journal of Production Economics, 79(3), 197-208 (2002)

24. Torkkeli, M., Tuominen M.: The Contribution of Technology Selection to Core Competencies. International Journal of Production Economics, 77(3), 271-284 (2002).

25. Suresh, N.C., Meredith, J.R.: Justifying Multimachine Systems: An Integrated Strategic Approach. Journal of Manufacturing Systems, 4(2), 117-134 (1985)

26. Gregory, M.: Technology Management: A Process Approach. In Proceedings of the Institution of Mechanical Engineers, Part B: Journal of Engineering Manufacture, 209(5), 347-356 (1995) 